\title{
NOTE
}

\section{Total sample area and estimates of species richness in exposed sandy beaches}

\author{
Eduardo Jaramillo', Anton McLachlan'², Jenifer Dugan ${ }^{3}$ \\ ${ }^{1}$ Instituto de Zoología, Universidad Austral de Chile, Casilla 567, Valdivia, Chile \\ ${ }^{2}$ Zoology Department, University of Port Elizabeth, PO Box 1600, Port Elizabeth 6000, South Africa \\ ${ }^{3}$ Marine Science Institute, University of California, Santa Barbara, California 93106, USA
}

\begin{abstract}
Recent studies have shown that macroinfaunal species richness of exposed sandy beaches increases from reflective to dissipative conditions. To analyse if this trend is affected by sampling strategies (primarily area sampled), we compared results from surveys carried out in different beach types of South Africa, Australia and Chile. Total area sampled in those surveys was $4.5 \mathrm{~m}^{2}$. The percentage of species predicted for each beach increased in relation to an increase in total sampling area. Only at a total sample area of $4 \mathrm{~m}^{2}$ were most ( $>95 \%$ ) of the species present collected. Sampling areas of $1 \mathrm{~m}^{2}$ and $2 \mathrm{~m}^{2}$ result in average underestimations of nearly $40 \%$ and $20 \%$ of the species, respectively. Beaches harbouring the highest number of species (the most dissipative ones) need to be sampled more extensively to collect most of the species, as compared with beaches having lower species nichness. A bibliographic survey showed that most of the studies carried out on sandy beaches have been based upon sampling areas considerably smaller than 4 to $4.5 \mathrm{~m}^{2}$, suggesting that in many of the studies the sandy beach macrofauna was undersampled.
\end{abstract}

KEY WORDS: Sandy beach macroinfauna - Species-area relationships

Studies carried out on sandy beaches of the northwest of USA, South Africa, Australia and south-central Chile (McLachlan 1990, Jaramillo \& McLachlan 1993, McLachlan et al. 1993) have shown that beaches of different morphodynamic types harbour differences in macrofaunal community attributes including species richness, abundance and biomass. Species richness increases linearly from reflective to dissipative conditions (e.g. McLachlan et al. 1993). Although changes in beach type appear to result in predictable changes in macrofaunal species richness, it is also possible that the above general trends may be affected by sampling strategies, primarily area sampled.

Materials and methods. To examine the possibility that estimates of species richness may be affected by sampling strategy (specifically, the area sampled), species-area relationships from a range of morpho- dynamic beach types were compared using data from macroinfaunal surveys of exposed sandy beaches on the coasts of south-central Chile, southeastern South Africa, and southern and northeastern Australia (Table 1). The beach state index calculated for each site shows that the beaches examined spanned a wide range of morphodynamic beach types. Three replicate samples of sediments (each $0.1 \mathrm{~m}^{2}$ in area and $25 \mathrm{~cm}$ deep) were collected at 15 equally spaced levels along a transect extending from above the drift line to the lower limit of the swash zone (the across-shore strategy). Total area sampled was $4.5 \mathrm{~m}^{2}$. The sediment was sieved through $1 \mathrm{~mm}$ mesh and the collected animals stored in 5\% formalin until sorting. A program based on probability theory (Hartnoll 1983) was used to construct species-area curves for sample areas up to $5 \mathrm{~m}^{2}$

Table 1. Beach characteristics for the sandy beaches studied at each geographic area. BSI: beach state index in which values $<0.5$ are for reflective beaches, 0.5 to 1.0 are for intermediate beaches, 1.0 to 1.5 for dissipative beaches and 1.5 to 2.0 for fully dissipative beaches (McLachlan et al. 1993). The Chilean beaches were sampled in September 1993, the South African one in July 1993 and those of Australia in July 1992

\begin{tabular}{|c|c|c|c|}
\hline Site & Area & $\mathrm{BSI}$ & Type of beach \\
\hline \multicolumn{4}{|l|}{ Chile } \\
\hline Los Molinos & Temperate & 0.50 & Reflective, microtidal \\
\hline Mehuín & Temperate & 1.50 & Dissipative, microtidal \\
\hline \multicolumn{4}{|l|}{ South Africa } \\
\hline King Beach & $\begin{array}{l}\text { Warm } \\
\text { temperate }\end{array}$ & 0.95 & Intermediate, microtidal \\
\hline \multicolumn{4}{|l|}{ Australia } \\
\hline Coorong & Temperate & 1.03 & Dissipative, microtidal \\
\hline Goolwa & Temperate & 1.28 & Dissipative, microtidal \\
\hline Mckay & Tropical & 1.42 & Ultradissipative, macrotidal \\
\hline Grasstree & Tropical & 1.52 & Ultradissipative, macrotidal \\
\hline Sarina & Tropical & 1.43 & Ultradissipative, macrotidal \\
\hline Cassuarina & Tropical & 1.79 & Ultradissipative, macrotidal \\
\hline
\end{tabular}


for each beach. A second sampling strategy (the alongshore strategy) was used on 2 beaches studied in Chile. Five samples of sediment $\left(0.03 \mathrm{~m}^{2}\right.$ each) were collected at 5 equally spaced levels along 30 transects $11 \mathrm{~m}$ apart) extending from above the drift line to the lower limit of the swash zone. Since the five $0.03 \mathrm{~m}^{2}$ samples of each of the 30 transects were pooled $10.15 \mathrm{~m}^{2}$ for each transect), the total area sampled under both strategies was $4.5 \mathrm{~m}^{2}$. The 2 sampling strategies used in Chile allowed analysis of the effect of number of beach levels sampled on estimates of species richness.

Results. Table 2 shows the results for the acrossshore strategy. The percentage of species predicted for each beach increased in relation to an increase in total sampling area. The number of species at $5 \mathrm{~m}^{2}$ sampling area was arbitrarily taken to be $100 \%$, recognizing that the curves never flatten out completely and thus never reach $100 \%$ in absolute terms. Only at a total sample area of $4 \mathrm{~m}^{2}$ were most (>95\%) of the species present collected. Sampling areas of $1 \mathrm{~m}^{2}$ and $2 \mathrm{~m}^{2}$ resulted in average underestimations of nearly 40 and $20 \%$ of the species, respectively (Table 2). The curves which repiesent the siluation for each beach ( 15 beach levels sampled) are shown in Fig. 1. The highest species richness was found towards more dissipative conditions (cf. Fig. 1 and Table 1). Beaches harbouring the highest number of species (Cassuarina and Serina in Australia) need to be sampled more extensively to collect most of the species, as compared with beaches having lower species richness (Fig. 1). As number of species present increases, total sampling area needs to be increased.

Fig. 2 shows the results of the comparison of sampling strategies for the Chilean beaches. Number of

Table 2. Total number of species recorded as a function of sampling area on sandy beaches: total number of species collected ( $\mathrm{n})$ and predicted percentage of species with increase in sampling area

\begin{tabular}{|c|c|c|c|c|c|c|}
\hline Sites & $\mathrm{n}$ & $1 \mathrm{~m}^{2}$ & $2 \mathrm{~m}^{2}$ & $3 \mathrm{~m}^{2}$ & $4 \mathrm{~m}^{2}$ & $5 \mathrm{~m}^{2}$ \\
\hline \multicolumn{7}{|l|}{ Chile } \\
\hline Los Molinos & 6 & 76.8 & 90.3 & 96.0 & 98.8 & 100 \\
\hline Mehuin & 9 & 73.7 & 86.3 & 93.2 & 97.7 & 100 \\
\hline \multicolumn{7}{|l|}{ South Africa } \\
\hline King Beach & 11 & 48.5 & 72.9 & 86.7 & 95.4 & 100 \\
\hline \multicolumn{7}{|l|}{ Australia } \\
\hline Coorong & 11 & 61.4 & 78.3 & 89.0 & 96.8 & 100 \\
\hline Goolwa & 13 & 56.9 & 77.3 & 89.0 & 96.7 & 100 \\
\hline McKay & 13 & 60.8 & 79.7 & 90.2 & 96.9 & 100 \\
\hline Grasstree & 19 & 49.4 & 70.7 & 84.9 & 95.6 & 100 \\
\hline Serina & 20 & 64.0 & 81.2 & 90.7 & 96.9 & 100 \\
\hline Cassuarina & 28 & 63.1 & 81.5 & 91.3 & 97.2 & 100 \\
\hline \multicolumn{2}{|c|}{ Average $\%$ : } & 61.6 & 79.8 & 90.1 & 96.9 & 100 \\
\hline
\end{tabular}

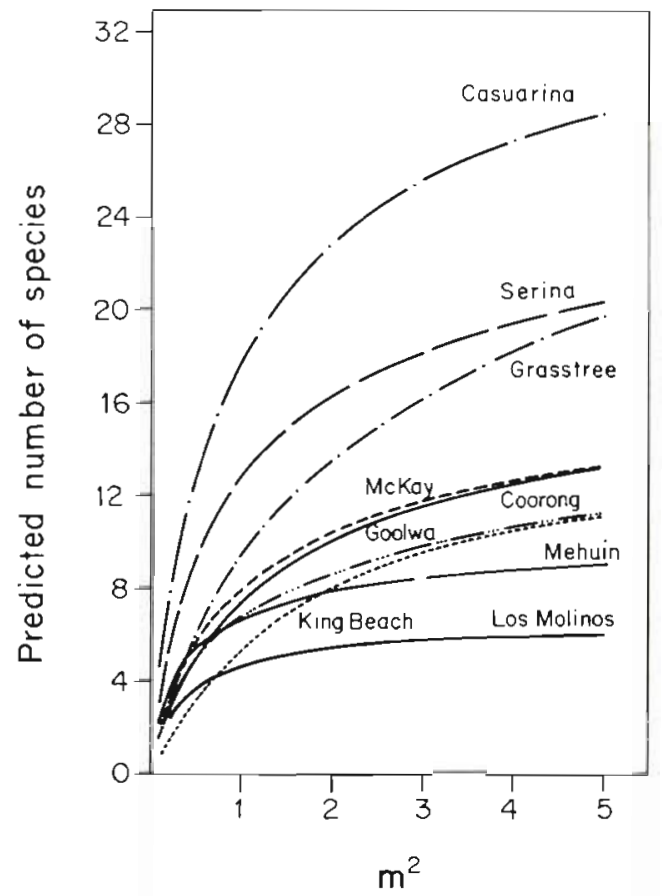

Fig. 1. Predicted number of species in relation to an increase in sampling area ( 15 levels sampled at each beach)

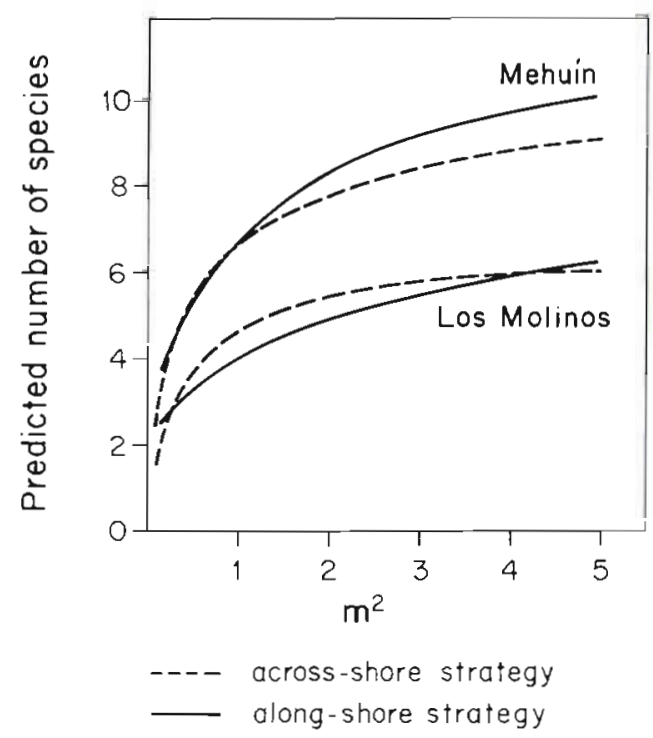

Fig. 2. Predicted number of species in relation to an increase in sampling area with the 2 sampling strategies used on the 2 beaches studied in Chile (see text)

beach levels sampled does not affect the estimates of species richness, since both strategies produced a similar trend; i.e. a larger area of the dissipative beach of Mehuin needs to be sampled to collect most of the species, as compared with the reflective beach of Los Molinos which had a lower species richness. 
Discussion. The overall results of these analyses have profound implications for sandy beach ecology and biodiversity of sandy beach macrofauna. Most of the surveys carried out on sandy beaches have been based upon sampling areas considerably smaller than $4.5 \mathrm{~m}^{2}$. This assertion is based upon a survey we carried out about sampling methodologies reported in 31 published studies from which clear information on sampling areas could be collected (Table 3). We do not claim that this survey is a complete one; however, it clearly shows that in many of the studies the sandy beach macrofauna was undersampled; i.e. the areas sampled were $\leq 1 \mathrm{~m}^{2}$. Only in 2 of these studies, the authors sampled a total area of 4 to $4.5 \mathrm{~m}^{2}$ (or more) (Bally 1983, Donn \& Cockcroft 1989), the area that our analysis demonstrated as necessary to obtain $>95 \%$ of the macrofaunal species living on exposed sandy beaches of a variety of morphodynamic types. In 4 of the studies, the authors sampled as much as $4 \mathrm{~m}^{2}$ (or more), but only in 1 or some of the studied sites (Gauld

Table 3. Total area sampled $\left(\mathrm{m}^{2}\right)$ in sandy beach surveys around the world. Ranges are given when different total areas were sampled in the same study

\begin{tabular}{|c|c|c|}
\hline Source & Location & $\begin{array}{l}\text { Area } \\
\text { sampled }\end{array}$ \\
\hline Gauld \& Buchanan (1956) & Ghana & $3.50-5.00$ \\
\hline Wood (1968) & New Zealand & 2.00 \\
\hline Seed \& Lowry (1973) & Ireland & $1.88-2.50$ \\
\hline Dexter (1974) & $\begin{array}{c}\text { Costa Rica, } \\
\text { Colombia }\end{array}$ & $1.20-4.80$ \\
\hline Croker et al. (1975) & USA & $0.60-0.72$ \\
\hline Dauer \& Simon (1975) & USA & 2.40 \\
\hline Dexter (1976) & Mexico & $2.00-4.00$ \\
\hline Croker $(1977)$ & USA & $0.60-0.72$ \\
\hline McLachlan (1977) & South Africa & 3.00 \\
\hline Jaramillo (1978) & Chile & $0.90-1.44$ \\
\hline Dexter (1979) & Panama & 3.00 \\
\hline Wooldridge et al. (1981) & South Africa & $2.00-3.25$ \\
\hline Koop \& Griffiths (1982) & South Africa & 2.50 \\
\hline Sánchez et al. (1982) & Chile & $1.70-2.50$ \\
\hline Bally (1983) & South Africa & 4.00 \\
\hline Knott et al. (1983) & USA & 1.35 \\
\hline Dexter (1984) & Australia & 1.20 \\
\hline Wendt \& McLachlan (1985) & South Africa & $2.00-2.50$ \\
\hline Ismail (1986) & Red Sea & 0.15 \\
\hline Dexter (1986/1987) & Israel, Egypt & $0.30-0.40$ \\
\hline Jaramillo (1987) & Chile & $0.60-1.30$ \\
\hline Jaramillo et al. (1987) & USA & $0.48-0.60$ \\
\hline Clarke \& Peña (1988) & Chile & 0.72 \\
\hline Dexter (1989) & Egypt & 0.64 \\
\hline Donn \& Cockcroft (1989) & Namibia & $6.00-8.40$ \\
\hline Dexter (1990) & Portugal & 0.16 \\
\hline Larsen \& Doggett (1990) & USA & 0.50 \\
\hline Jaramillo \& González (1991) & Chile & $0.54-0.60$ \\
\hline Perez Edrosa \& Junoy (1991) & Spain & $1.92-2.08$ \\
\hline Defeo et al. (1992) & Uruguay & $1.65-4.29$ \\
\hline Jaramillo \& McLachlan (1993) & Chile & 1.20 \\
\hline
\end{tabular}

\& Buchanan 1956, Dexter 1974, 1976, Defeo et al. 1992).

The total area needed to be sampled in macrofauna surveys targeted to find out estimates of species richness depends on beach type and tide range. The slope of curves presented in Fig. 1 suggests that for microtidal beaches (Los Molinos, Mehuín, King Beach, Coorong, Goolwa) a sample area of 3 to $4 \mathrm{~m}^{2}$ reaches the point where the curves start flattening However, for the macrotidal beaches greater sampling effort is required, probably at least $5 \mathrm{~m}^{2}$.

Acknowledgements. The work in Chile was made possible by financial support from CONICYT (Chile) through FONDECYT research project $92 / 191$ and Universidad Austral de Chile (DID project S92/36) to E.J.; that in Australia and South Africa was supported by South Africa FRD Core Grant to A.M. We thank the following people who assisted us in the field: in Chile, Pedro Quijón, Marcia González, Jacqueline Muñoz, María Avellanal, Heraldo Contreras, Robert Brumer, Robert Stead, and Victor Poblete; in Australia, An de Ruyck; in South Africa, An de Ruyck, Mariano Lastra, Alexandre Soares, Andrew Bentley, Ted Donn, and David Schoeman. We also thank 3 anonymous referees for comments on an earlier manuscript.

\section{LITERATURE CITED}

Bally, R. (1983). Intertidal zonation on sandy beaches of the west coast of South Africa. Cah. Biol. mar. 24: 85-103

Clarke, M., Peña, R. (1988). Zonación de la macroinfauna en una playa de arena del norte de Chile. Estud. Oceanol. 7 : $17-31$

Croker, R. A. (1977). Macroinfauna of northern New England marine sand: long-term intertidal community structure. In: Coull, B. C. (ed.) Ecology of marine benthos. Belle W. Baruch Library in Marine Science No. 6. Univ. of S. Carolina Press, p. 439-450

Croker, R. A., Hager, R. P., Scott, K. J. (1975). Macroinfauna of northern New England marine sand. II. Amphipod-dominated intertidal communities. Can. J. Zool. 53: 42-51

Dauer, D. M., Simon, J. L. (1975). Lateral or along-shore distribution of the polychaetous annelids of an intertidal, sandy habitat. Mar. Biol. 31: 363-370

Defeo, O., Jaramillo, E., Lyonnet, A. (1992). Community structure and intertidal zonation of the macroinfauna on the Atlantic coast of Uruguay. $J$. coast. Res. 8: 830-839

Dexter, D. M. (1974). Sandy-beach fauna of the Pacific and Atlantic coasts of Costa Rica and Colombia. Rev. Biol. Trop. 22: 51-66

Dexter, D. M. (1976). The sandy-beach fauna of Mexico. Southwest. Nat. 20: 479-485

Dexter, D. M. (1979). Community structure and seasonal variation in intertidal Panamanian sandy beaches. Estuar. coast. mar. Sci. 9: 543-558

Dexter, D. M. (1984). Temporal and spatial variability in the community structure of the fauna of four sandy beaches in south-eastern New South Wales. Aust. J. mar. Freshwat. Res. 35: 663-672

Dexter, D. M. (1986/87). Sandy beach fauna of Mediterranean and Red Sea coastlines of Israel and the Sinai peninsula. Isr. J. Zool. 34: 125-138

Dexter, D. M. (1989). The sandy beach fauna of Egypt. Estuar. coast. Shelf Sci. 29: 261-271 
Dexter, D. M. (1990). The effect of exposure and seasonality on sandy beach communty structure in Portugal. Cienc. Biol. Ecol. Syst. (Portugal) 10:31-50

Donn, T. E., Cockcroft, A. C. (1989). Macrofaunal community structure and zonation of two sandy beaches on the central Namib coast, South West Africa/Namibia. Madoqua 16: $129-135$

Gauld, D. T., Buchanan, J. B. (1956). The fauna of sandy beaches in the Gold Coast. Oikos 7: 293-301

Hartnoll, R. G. (1983). The species-area relationship on a sandy beach. In: McLachlan, A., Erasmus, T. (eds.) Sandy beaches as ecosystems. Dr $W$. Junk Publishers, The Hague, p. 473-479

Ismail, N. (1986). Community structure of macrobenthic invertebrates in sandy beaches of the Jordan Gulf of Aqaba, Red Sea. Int. Rev. ges. Hydrobiol. 71: 225-232

Jaramillo, E. (1978). Zonación y estructura de la comunidad macrofaunística en playas de arena del sur de Chile (Mehuín, Valdivia). Stud. Neotrop. Fauna Environ. 13: 71-92

Jaramillo, E. (1987). Sandy beach macroinfauna from the Chilean coast: zonation patterns and zoogeography. Vie Milieu 37: 165-174

Jaramillo, E., Croker, R. A., Hatfield, E. B. (1987). Long-term structure, disturbance, and recolonization of macroinfauna in a New Hampshire sand beach. Can. J. Zool. 65: $3024-3031$

Jaramillo, E., González, M. (1991). Community structure and zonation of the macroinfauna along a dissipative reflective range of beach category in southern Chile. Stud. Neotrop. Fauna Environ. 26: 193-212

Jaramillo, E., McLachlan, A. (1993). Community and population responses of the macroinfauna to physical factors over a range of exposed sandy beaches in south-central Chile. Estuar. coast. Shelf. Sci. 37: 615-624

Knott, D. M., Calder, D. R, Van Dolah, R. F. (1983). Macrobenthos of sandy beach and nearshore environments at Murrells Inlet, South Carolina, U.S.A. Estuar, coast. Shelf

This note was submitted to the editor
Sci. 16: 573-590

Koop, K., Griffiths, C. L. (1982). The relative significance of bacteria, meio- and macrofauna on an exposed sandy beach. Mar. Biol. 66: 295-300

Larsen, P. F., Doggett, L. F. (1990). Sand beach macrofauna of the Gulf of Maine with inference on the role of oceanic fronts in determining community composition. J. coast. Res. 6: 913-926

McLachlan, A. (1977). Composition, distribution, abundance and biomass of the macrofauna and meiofauna of four sandy beaches. Zool. Afr. 12: 279-306

McLachlan, A. (1990). Dissipative beaches and macrofauna communities on exposed intertidal sands. J. coast. Res. 6: $57-71$

McLachlan, A., Jaramillo, E., Donn, T. E., Wessels, F. (1993). Sandy beach macrofauna communities and their control by the physical environment: a geographical comparison. J. coast. Res. (Spec. Issue) 15: 27-38

Perez Edrosa, J. C., Junoy, J. (1991). Macrofauna intermareal de las playas de Area Longa, Peizas y Anguieira y Altar (Lugo, NW España). Thalassas 9: 37-48

Sánchez, M., Castilla, J. C., Mena. O. (1982). Variariones verano-invierno de la macrofauna de arena en playa Morrillos (Norte Chico, Chile). Stud. Neotrop. Fauna Environ 17: $31-49$

Seed, R., Lowry, B. J. (1973). The intertidal macrofauna of seven sandy beaches of County Down. Proc. R. Irish Acad. B 73: $217-230$

Wendt, G E., McLachlan, A. (1985). Zonation and biomass of the intertidal macrofauna along a South African sandy beach. Cah. Biol. mar. 26: 1-14

Wood, D. H. (1968). An ecological study of a sandy beach near Auckland, New Zealand. Trans. R. Soc. N.Z., Zool. 10: $89-115$

Wooldridge, T., Dye, A. H., McLachlan, A. (1981). The ecology of sandy beaches in Transkei. S. Afr. J. Zool. 16: $210-218$

Manuscript first received: July 14, 1994

Revised version accepted: December 27, 1994 